\title{
Mixteca genealogies. Dynastic history? Mythology? or cosmology? The case of Lord 8-Deer
}

\author{
Arnold Lebeuf
}

\begin{abstract}
:
This essay overviews the interpretations of the narrative of a character called 8-Mazatl from Mixtec codices. While there has been a recent interpretation that tried again to understand this narrative as a historical source, more traditional interpretations linked the narrative to mythological characters and events.

This paper explores the possibility of using the mythological interpretations of celestial bodies to link the story to the long scale cycles related with eclipses.
\end{abstract}

Keywords: Mixteca genealogies, cosmology, archaeoastronomy, Lord 8-Deer

\begin{abstract}
o:
LAS GENEALOGÍAS DE LA MIXTECA ¿HISTORIA DINÁSTICA? ¿MITOLOGÍA?

¿O COSMOLOGÍA? EL CASO DEL SEÑOR 8-MAZATL

EL autor del ensayo examina las interpretaciones de la narrativa del personaje llamado 8-Mazatl de los códices mixtecos. Si bien ha habido una interpretación reciente que ha intentado de nuevo entender esta narrativa como fuente histórica, hay interpretaciones más tradicionales que vinculan la narrativa con personajes y acontecimientos mitológicos.

Este artículo analiza la posibilidad de utilizar las interpretaciones de los mitos en las observaciones astronómicas.
\end{abstract}

Palabras clave: genealogías Mixteca, cosmología, arqueoastronomía, Señor 8-Mazatl

Arnold Lebeuf - Institute for the History of Religions, Jagiellonian University, Cracow. Email a.lebeuf@iphils.uj.edu.pl 
Between themselves, the priests and the first of them achcauhtli, a very high dignity, they learn and teach the mysteries of their religion by words and figures but do not communicate nor discover them to the others, under threat of very heavy punishment. Lopez de Gomara 2000:465-466

\section{Introduction}

The words of Lopez de Gomara confirm what is known of every ancient culture. Astronomy and cosmology are the monopoly of the religious class, they are jealously kept and only taught in cryptic manner.

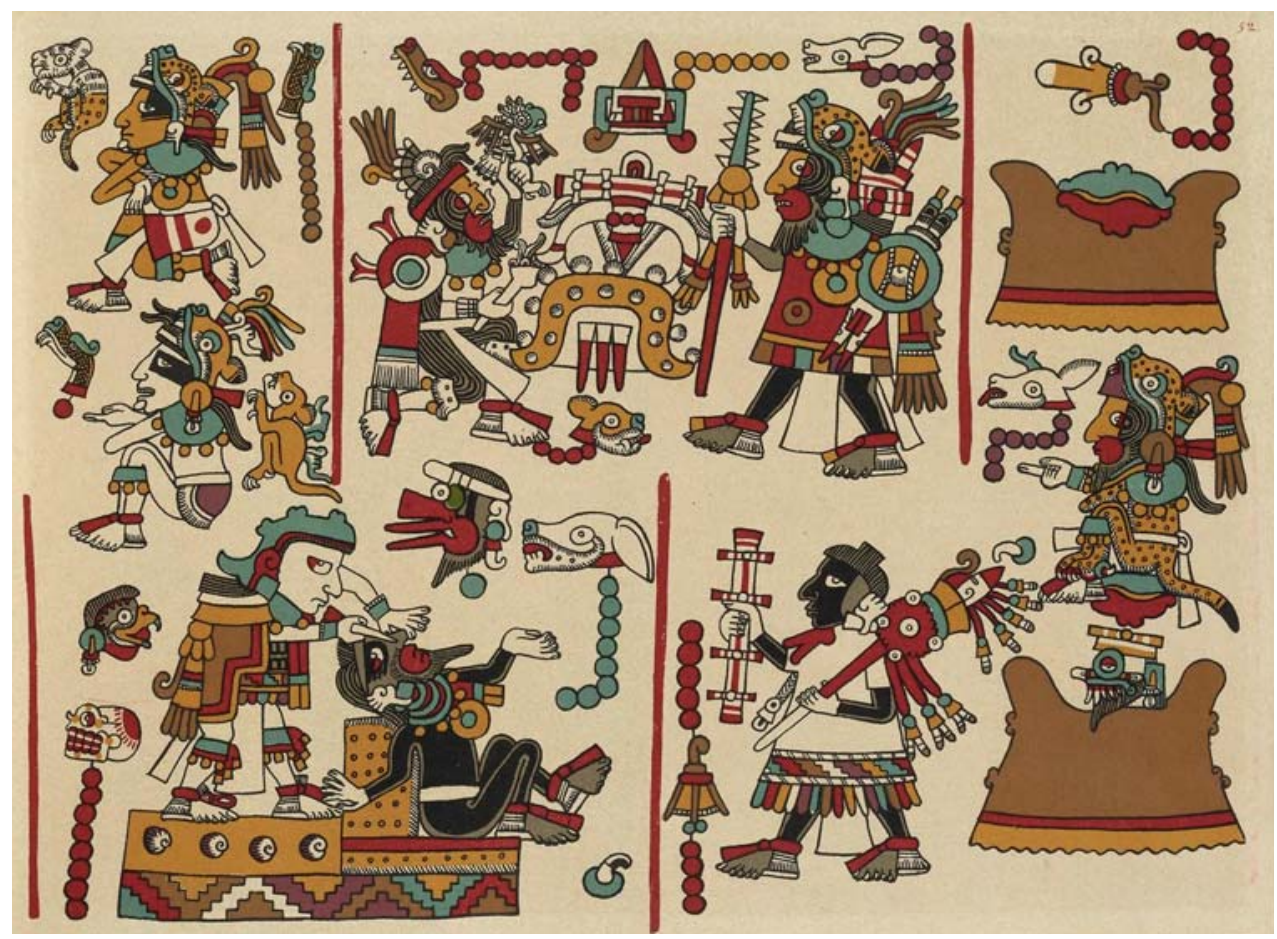

Codice Nutall, pl.52, (source Nuttall Zouche 1902[2018]:84, public domain)

In his 2006 paper, Los señoríos de Ñu Zauzi y la expansión tolteca Maarten Jansen treats of the career of a certain Lord 8-Mazatl (8-Deer), a prominent actor of Mixtec codices who according to him lived between 1063 and 1115 A.D. and visited Lord 4-Jaguar in Cholula to receive his legitimation as a ruler in the Mixteca. Jansen presents several arguments to claim that Lord 4-Ocelotl of Cholula was the real historical Topiltzin Quetzalcoatl. He finds all the story very clear. For example, he writes: 
"If we ask ourselves "which city, known as Tollan, is situated a few days walk to the North of the Mixteca, in a plane land, which is reached after passing a mountain covered with snow?

- The answer is easy: It must be Tollan-Chollolan, that is to say Cholula" (Jansen 2006:182).

Or:

"The mentioned chronicles do not leave any space for doubt concerning the identity of the governor of Cholula in that epoch: No one less than the famous Ce Acatl, Nacxitl, Topiltzin, the 'Historical Quetzalcoatl'( Jansen 2006:191).

Or:

"Once established this context, it is easy to understand that it is exactly to this figure (Quetzalcoatl) that the Lord 8-Mazatl went to obtain his status and legitimacy" (Jansen 2006:203).

Everything is apparently crystal clear for Jansen who nevertheless also expresses some doubts:

"Isolated, each one of the elements of that reasoning offers only a certain probability, and for that reason could be questioned" (Jansen 2006:203).

The historical reality of all that is a separate problem. The biography of Lord 8-Mazatl contains many indications showing that it has been structured according to narrative and dramatic principles (Jansen 2006:203).

All the same, he feels that the identification of 4-Ocelotl with the historical Quetzalcoatl is evident.

According to Jansen, in fairly good agreement with Alfonso Caso and other authors, the story told is such:

1. Lord 8-Mazatl went to Cholula to receive the legitimation of his status as a king of the Mixteca from the high priest who was then a certain 4-Ocelotl, according to Jansen, the historical and real Topiltzin Quetzalcoatl.

2. Lord 8-Mazatl had the nasal septum pierced and received the nose ornament, a bar of turquoise from Lord 4-Ocelotl on a day 1-Ehecatl.

3. Lord 8-Mazatl and Lord 4-Ocelotl became allies and went together on various military expeditions.

4. Lord 8-Mazatl found protection and support from Lady 9-Malinalli, a goddess associated to the Mexican Cihuacoatl Quilaztli.

5. Lord 8-Mazatl and Lord 4-Ocelotl went together to visit Lord 1-Miquiztli at the Sun temple of Chichen Itza,

6. Lord 8-Mazatl offered a sacrifice to the Solar God 13-Acatl.

7. Last, Lord 8-Mazatl is assassinated by Lord 4-Ehecatl who becomes then the "strong Man", or leader in Nuu Dzaui, Mixteca, and the murderer Lord 
4-Ehecatl receives confirmation of his power by the piercing of his nasal septum and the nose ornament obtained from the same Lord 4-Ocelotl, alias Topiltzin Quetzalcoatl who had offered at the beginning of the story the same dignity to his former ally Lord 8-Mazatl, now the victim of Lord 4-Ehecatl.

Of course, to establish the biography of this gentleman on the base of such pictorial documents requires some imagination.

\section{Doubting historical interpretations. From mythology to cosmology}

Jill Leslie Furst $(1977 ; 1978)$ has already criticized all historical interpretation of those Mixtec codices, claiming that all was mere mythology and it was useless to look for any historical data or dates in them.

I fully agree with the conclusions of Jill Leslie Furst, these documents cannot be read as dynastic chronicles, but this does not imply they do not contain some chronological information. I would like to present in this essay another possibility for the understanding of these codices. A cryptic transmission of cosmological and astronomical knowledge .

First, I agree that the whole story bears a strong link to Cholula and Quetzalcoatl. Not only 4-Ocelotl bears attributes and features of Quetzalcoatl, but 8-Mazatl as well. The son of a priest protected by Cihuacoatl-Quilaztli, murdered at the age of 52 seems indeed a kind of double of Quetzalcoatl.

Jansen does not notice that the life span of 8-Mazatl is of 52 years, the canonical age of Toltec kings and of Men-Gods described by Alfredo López Austin (1998), all of them so far from being historical. 52 years is as well the length of a Mesoamerican small "century" when the two cycles of 365 and 260 days are congruent, 52 days is moreover the derivation inside the Tonalpohualli of the nodes of moon orbit during one Sun of 1040 years. All this already should attract our attention on some possible cosmological explanation. Quetzalcoatl was the master of the sacred 260 days cycle, and had strong connections to Venus and the eclipse cycles.

Now, there is a strange thing in the names of two of the protagonists of that story. The high priest and king in Cholula is called 4-Ocelotl, and the successor of 8-Mazatl is called 4-Ehecatl. 4-Ocelotl and 4-Ehecatl are the calendar names of the first two Suns of Aztec Cosmology. Last, Lord 8-Mazatl offers a sacrifice to 13-Acatl, a prominent date on the Aztec calendar stone.

Jansen also informs us that: "To demonstrate his courage and fidelity, Lord 8-Mazatl conquered for Lord 4-Ocelotl the mountain of the Moon (Jansen, 2006:191, n. 20). This might constitute another reference to cosmological matters. 


\section{The 260 day calendar and eclipse zones}

Back in 1930 Hans Ludendorff claimed the Tonalpohualli was a small computer for eclipses (Ludendorff 1930). Three equidistant days in the 260 days cycle mark the passage of the Sun on the nodes of moon orbit. The three eclipse zones are of 35 days each and between them are left three zones of 52 days free of eclipses (Figure 1).

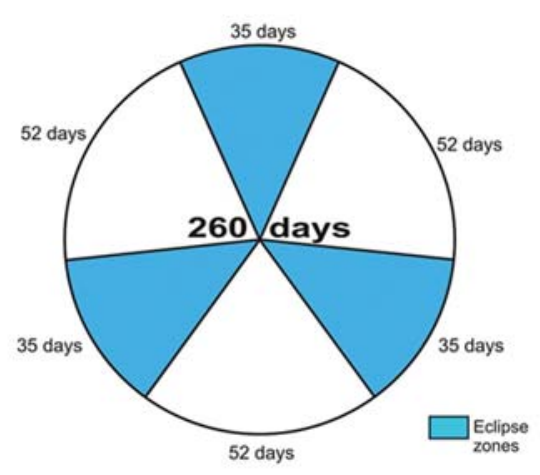

Figure 1

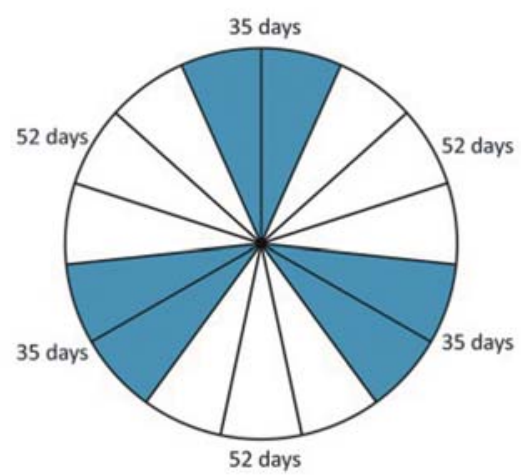

Figure 2

35 is roughly twice 17 and 52 is roughly three times 17 , so the 260 days wheel can be divided in fifteen zones of 17,33333 days each (Figure 2).

But Mesoamerican arithmetic does not accept fractions or decimals. And the multiplication of 17 by 15 gives 255 and therefore five units more have to be inserted (regularly if possible) to reach 260 .

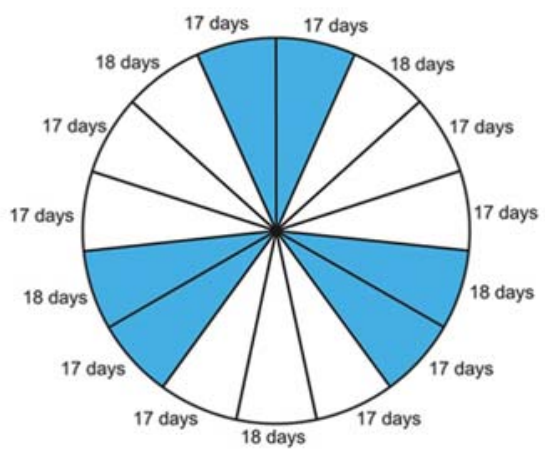

Figure 3

The division of the Tonalpohualli can be arranged as:

$17,18,17,17,18,17,17,18,17,17,18,17,17,18,17$.

This arrangement would give us the following distances from any zero starting point:

$0+17=17,+18=35,+17=52,+17=69,+18=87,+17=104,+17=121,+18$ $=139,+17=156+17=173+18=191,+17=208,+17=225,+18=243,+17=260$. 
Now a table of all respective distances between the seven dates found in the Lord 8-Mazatl story can be constructed.

Table 1

\begin{tabular}{|c|c|c|c|c|c|c|c|}
\hline & 4-Ocelotl & 8-Mazatl & 4-Ehecatl & 9-Malinalli & 1-Ehecatl & 1-Miquiztli & 13-Acatl \\
\hline 4-Ocelotl & $0 / 260$ & 173 & 208 & $242-$ & 172- & $192+$ & 139 \\
\hline 8-Mazatl & 87 & $0 / 260$ & 225 & $155-$ & $175+$ & $241-$ & 226- \\
\hline 4-Ehecatl & 52 & 35 & $0 / 260$ & 190- & $140+$ & $244+$ & 191 \\
\hline 9- Malinalli & $18+$ & $105+$ & $70+$ & $0 / 260$ & 191 & $174+$ & 139 \\
\hline 1-Ehecatl & $88+$ & $85-$ & $120-$ & 69 & $0 / 260$ & 156 & $209+$ \\
\hline 1-Miquiztli & 68- & $19+$ & $16-$ & 86- & 104 & $0 / 260$ & $207-$ \\
\hline 13-Acatl & 121 & 34- & 69 & 121 & 51- & $53+$ & $0 / 260$ \\
\hline \multicolumn{8}{|c|}{$\begin{array}{l}\text { Out of } 42 \text { distance numbers: } \\
16 \text { fall exactly on the ideal date. } \\
22 \text { at just one day apart } \\
4 \text { at two days apart }\end{array}$} \\
\hline
\end{tabular}

It must be noted that by using entire numbers the table seems to be of great relevance, and all the figures of the 8-Mazatl narrative are present in the table and all theoretical distance numbers of a division of the Tonalpohualli in sequences of $17 / 17 / 18$ days are also attested.

\section{The story and the reconstruction of cosmological history}

The three eclipse zones regress (anticlockwise) slowly in the Tonalpohualli at the rate of one day for twenty years, so that each day in the Tonalpohualli can be free of eclipses during 1040 years ( $52 \times 20)$.

In the year $3120 \mathrm{BC}$, dies the last of the five suns of the preceding Cosmology of 5200 years. That year, the day 13-Acatl, the name of the fifth and last Sun of the previous world enters an eclipse zone, transmitting the cargo of time to the first Sun of the new 5200 years cycle, sun 4-Ocelotl.

13-Acatl is not interpreted here as it is usually as the day or year bearer of the Sun in general, but as the name of the last Sun of the previous 5200 years cosmology. When 13-Acatl dies, that is to say enters in an eclipse zone, in the year $3120 \mathrm{BC}$, then the day 4-Ocelotl comes out of an eclipse zone in the Tonalpohualli, marking the birth of the first Sun of the present 5200 years cycle. So metaphorically 13-Acatl may signify the date of the birth of the Sun, but only of the New Sun 4-Ocelotl, first one of the new Long Count. This is possible only by the death of the previous one 13-Acatl.

At the same time, when the day 4-Ocelotl escapes an eclipse zone, 8-Mazatl escapes a second eclipse zone, so that in respect to the nodes, 4-Ocelotl and 8-Mazatl are equivalents, that is why Lord 4-Ocelotl shares his power to 8-Mazatl on a day 1-Ehecatl, the third date escaping an eclipse zone in 3120 BC (Figure 4). 


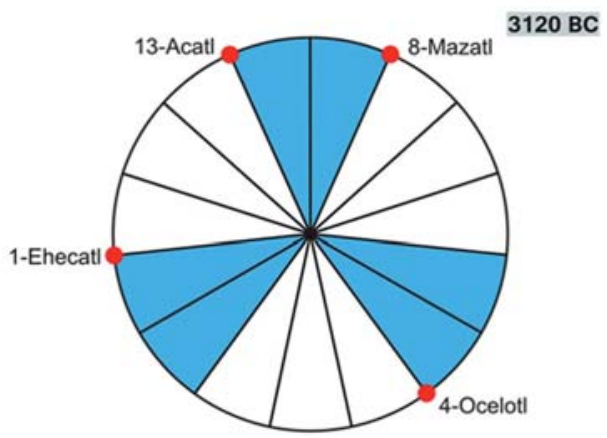

Figure 4

That is fine, all three offer the same indication of the moment of the birth of the first Sun of Aztec cosmology, in 3120 BC.

Now both 4-Ocelotl and 8-Mazatl become allies and lead together a life of wars and conquests. Both proceed together in their career for 1040 years when they reach the moment of their coming death, while the next eclipse zones are approaching.

So Lord 8-Mazatl, together with Lord 4-Ocelotl, rushes to the solar temple of Lord/god 1-Miquiztli for assistance.

It happens that 1-Miquiztli is in the same year $2080 \mathrm{BC}$ one of the three days marking the moments of the passages of the Sun on the nodes of Moon orbit (Figure 5). Most probably, by visiting the great Lord of eclipses, of the creations and destructions of consecutive suns, 8-Mazatl hopes his fate can be abolished or deleted, But nothing helps, and even god/ Lord 1-Miquiztli cannot stop the wheel of time turning inexorably.

So Lord 8-Mazatl runs to Lady 9-Malinalli, another name for CihuacoatlQuilaztli, the nurse of Quetzalcoatl, that is to his own mother, begging for help (Figure 5).

The day 9-Malinalli is then the second position of the nodal passage of the Sun in the Tonalpohualli. But neither the goddess can help, can stop time, and the death is ineluctable.

Resigned to his fate, Lord 8-Mazatl offers then a sacrifice to the Lord 13-Acatl (Figure 5).

By this sacrifice, 8-Mazatl probably wants to please Lord 13-Acatl to accept him, to welcome him in the other world, in the land of dead suns, in consideration of their common destiny. A thousand and forty years earlier, in 3120 BC, 13-Acatl was exactly in the same situation (Figure 6) as 8-Mazatl now in 2080 BC (Figure 7).

According to the program of cosmic order, 8-Mazatl dies then, assassinated by Lord 4-Ehecatl, a very logical thing, considering that 4-Ehecatl is the name of the second Sun of Aztec cosmology. In 2080 BC, 4-Ocelotl and his alter ego 8-Mazatl 


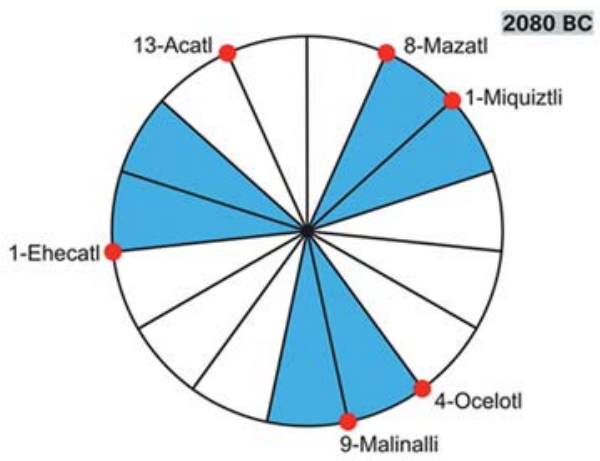

Figure 5

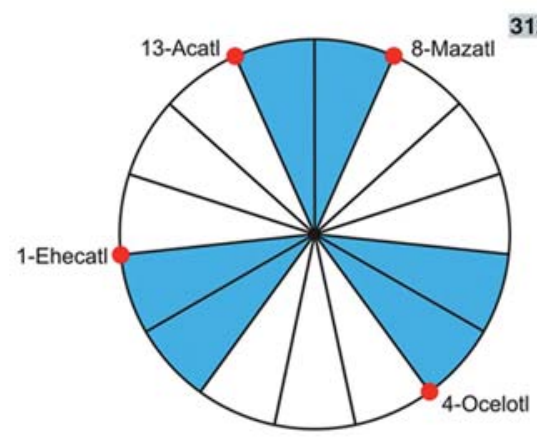

Figure 6

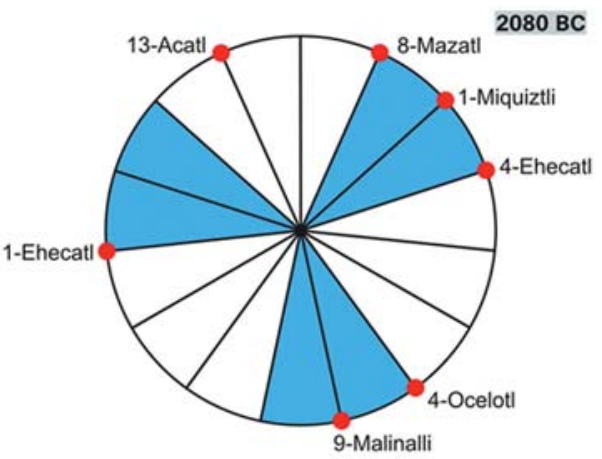

Figure 7

finish their career and must transmit the cargo of time to their successor 4-Ehecatl, the second Sun who is just coming out of an eclipse zone, will becomes the regent of the second Sun for the next 1040 years (Figure 7). 4-Ocelotl, the first Sun of Aztec cosmology transmits him the cargo, the power and legitimacy.

This apparently dynastic historical document might well then represent the cryptic transmission of a part of Mesoamerican cosmology, the birth and life of the first sun and the passage from the first to the second Sun of the Aztec reform.

\section{Acknowledgements:}

This article was written during the realization of my investigations on the identity of Quetzalcoatl under the title: "Topiltzin Actor, an analysis of the religious mystery in Pre-Hispanic Mesoamerica and its relations to calendar and astronomical aspects", a project supported by the National Science Centre of Poland, number 2013/11/B/HS1/04146) 


\section{References:}

Furst, Jill Leslie

1977 The Tree Birth Tradition in the Mixteca, Mexico, Journal of Latin American Lore, 3: 2: 183-226.1978 The year 1 Reed, day 1 Alligator: A Mixtec Metaphor, Journal of Latin American Lore, 4: 1: 93-128;

Lebeuf, Arnold

2003 Les éclipses dans l’ancien Mexique, éditions de l'Université Jagiellone, Cracovie,

López de López de Gomara,Francisco

2000 La conquista de México, Dastin, Madrid, 2000.

Jansen Maarten

2006 Los señoríos de Nu Zauzi y la expansión tolteca, Revista Española de Antropología Americana, vol.36, num.2, 175-208, p.191-192.

López Austin, Alfredo

1998 Hombre-Dios, Religion y politica en el mundo nahuatl, UNAM, México.

Ludendorff, Hans

$1930 \quad$ Uber die Entstehung der Tzolkin-Periode im Kalendar der Maya, Preussischen Akad. der Wissenschafl, Phys.-Math. Klasse, Berlin.

Nuttall Zelia, Zouche, Robert Nathaniel Cecil George Curzon

1902[2018] Codex Nuttall; facsimile of an ancient Mexican codex belonging to Lord Zouche of Harynworth, England, Peabody Museum of Archaeology and Ethnology, Cambridge, https://archive.org/details/ gri_33125011146541

\section{Historical sources used:}

Codex Vindobonensis (folios: VIII-3, 2; VIII-3, 2, 1; IX-1, 2).

Codex Nuttal (folios: 26-II, III; 43 -I, II; 44-II, IV; 45-II, III, IV; 49-IV; 50-IV; 51-54; $68-70 ; 75-80 ; 82 ; 83)$.

Codex Bodley (folios: 7-V; 9-V a 14-IV; 34-IV, V; 30-III;29-IV).

Codex Selden (folios: 9-I)

Mapa de Teozacoalco I.

Codex Becker (folios: I; 1 a 14).

Relacion de Huautla, Tlalocan (folios: IV, p.15). 
